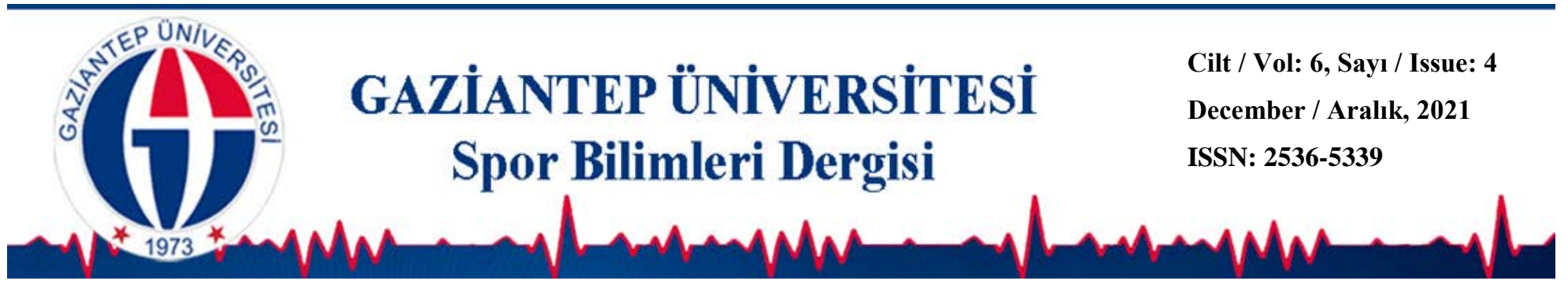

\title{
Spor Turizminde İnovasyonel Yaklaşımlar: E-Spor
}

\author{
Çilem BULUT' ${ }^{*}$ iD Savaş DUMAN ${ }^{1}$ iD \\ Hacı Murat ŞAHİN ${ }^{1}$ \\ Günseli DUMAN² iD \\ Ender Ali ULUÇ ${ }^{3}$ iD
}

\author{
${ }^{1}$ Adnan Menderes Üniversitesi Spor Bilimleri Fakültesi, AYDIN \\ ${ }^{2}$ Adnan Menderes Üniversitesi, Yabancı Diller Yüksekokulu, AYDIN \\ ${ }^{3}$ Çanakkale Onsekiz Mart Üniversitesi, Ayvacık Meslek Yüksekokulu, ÇANAKKALE
}

\section{doi)OI: 10.31680/gaunjss. 1019040}

\section{Orijinal Makale / Original Article}

Geliş Tarihi / Received: 11.08.2021 Kabul Tarihi / Accepted: 29.11.2021 Yayın Tarihi/ Published: 24.12.2021

\section{Öz}

Turizm; doğal, çevresel ve kültürel kaynaklara yoğun olarak ihtiyaç duyan ve bunları ekonomik girdi olarak kullanan bir endüstridir. Sporun dünyada geniş bir kitleye hitap etmesi, sosyal yaşantının gelişmesiyle birlikte her geçen gün bir talep artışı yaşanmasına ve önem derecesinin yükselmesine sebep olmuştur. Bu talep sporun turizme yönelmesine de imkân tanımıştır. Böylelikle spor turizmi sektörel bazda önem arz etmekte endüstriyel katkısı azımsanmayacak şekilde artmaktadır. Kısaca spor turizmi amatör veya profesyonel olarak bir sportif faaliyeti gerçekleştirmek, herhangi bir spor organizasyonunu seyirci olarak takip etmek veya sportif değeri olan turistik noktaları (müze, stadyum vb.) ziyaret etmek amacıyla yapılan seyahatler olarak tanımlamak mümkündür. Özellikle son dönemde popülaritesi artan spor branşları içerisinde yer alan E-Spor, spor turizmi açısından değerlendirildiğinde gerek izleyicisi gerekse sporcuları olarak çok önemli bir yer tuttuğu görülebilmektedir. Dijital oyunların gün geçtikçe popülaritesinin artış artması ve bu sektörün özellikle de genç nesil için bir motivasyon kaynağı olarak görülmesi ve genç yaş gruplarının spor turizmine katkısı açısından da E-Sporun önemini arttırmaktadır. Spor turizmi açısından E-Sporun değerlendirilmesi amacıyla yapılan bu araştırmada Spor turizmi ve E-Spor konularında yapılan araştırmalar doküman analizi yöntemi ile incelenmiş sonuç olarak; E-Spor turnuvalarına katılım sağlayan sporcuların ve seyircilerin bulundukları destinasyonda turist olarak değerlendirildikleri ve bu turnuvaların ülkelerin imajlarına olumlu yönde katkılar sağladığı sonucuna ulaşımıştır.

Anahtar Kelimeler: Turizm, Spor, E-Spor, Spor Turizmi

\section{Abstract}

\section{Innovative Approaches in Sports Tourism: E-Sports}

Tourism; It is an industry that needs natural, environmental and cultural resources intensively and uses them as economic inputs. The fact that sports appeal to a wide audience in the world has led to an increase in demand and an increase in importance with the development of social life. This demand also allowed sports to turn to tourism. Thus, sports tourism is important on a sectoral basis and its industrial contribution is increasing significantly. In short, it is possible to define sports tourism as travels made to perform an amateur or professional sporting activity, to follow any sports organization as a spectator, or to visit touristic points (museums, stadiums, etc.) with sporting value. E-Sports, which is one of the sports branches whose popularity has increased recently, can be seen to have a very important place in terms of sports tourism, both as spectators and athletes. The increasing popularity of digital games day by day and the fact that this sector is seen as a source of motivation especially for the young generation and the contribution of young age groups to sports tourism increases the importance of E-Sports. In this research, which was carried out to evaluate e-Sports in terms of sports tourism, researches on sports tourism and e-sports were examined by document analysis method; as a result; It has been concluded that the athletes and spectators participating in e-Sports tournaments are considered as tourists in their destination and these tournaments contribute positively to the images of the countries.

Keywords: Tourism, Sports, E-Sports, Sports Tourism

\footnotetext{
*Sorumlu Yazar: Çilem BULUT

e-mail: bulutcilem0@gmail.com

**Bu araştırma V. Uluslararası Akademik Spor Araştırmaları Kongresinde Sözel Bildiri Olarak Sunulmuştur
} 


\section{Giriş}

E-Spor, Elektronik Spor kelimesinin kısaltmasıdır. Durak (2020)'a göre, E-Spor; çevrimiçi video oyunları aracılığı ile, spor ortamında bulunan rekabeti ve takımlar arasındaki mücadeleyi birbiri ile entegre eden yeni nesil spor branşıdır. Wagner (2006)'a göre, E-Spor, profesyonel kuralları olan, karşılaşmaya dayalı bilgisayar oyunlarının, dijital bir ortamda oynanması olarak ifade edilmektedir. E-Sporun geçmişten günümüze kadar gelişimini özetleyecek olursak; bu dönemi Atari ve 2000'li yıllarda gelişen internet sonrası dönem olmak üzere iki ana gruba ayırabiliriz. Şakar (2021)'a göre, Atari oyunlarının ortaya çıkmasıyla birlikte oyun kültürü gelişmeye başlamıştır. 1987'li yıllarda popülaritesi artan oyunlardan elde edilen gelir, oyun pazarının ne kadar büyük olduğuna dikkat çekerek, bu pazarın bir sektöre dönüşmesine olanak tanımıştır. 1990'lı yılların sonunda internetin yaygınlaşması ve elektronik aygıtların maliyetlerinin azalmasıyla dijital oyunlar herkesin evlerinde, ulaşılabilir hale gelmiş, internetin getirdiği "çevrimiçi” olma durumu dijital oyunlara farklı bir boyut kazandırmıştır (Şakar, 2021). Böylelikle E-Spor oyuncuların farklı ülkelerden rakip bulmalarına ve bu rakiplerle yarışarak kendilerini diğer oyunculara kanıtlamalarına olanak tanımıştır. E-Spor günümüzde, insanların ruhsal olarak rahatlamalarına olanak tanıyan, her yaşa ve her kitleye hitap eden, aynı zamanda yeni iş alanları sağlayan bir olgu haline gelmiştir (Alioğlu ve Algül, 2021).

Kılınç (2019)'a göre, 2019 yılında en çok gelir sağlayan ücretli E-Spor oyunu 786 Milyon \$'luk gelir ile FIFA 19 olurken, ücretsiz olarak en çok kazanç sağlayan oyunlar arasında Fortnite yer almaktadır. Koç (2021)'e göre, 2020 yılında 1471 tane turnuva düzenlenerek 229.231.216,55 \$'ık ödül dağıtan Dota2 oyunu en çok ödül dağıtan E-Spor oyunu olarak belirtilmiştir. Esports Earnings'e göre, 2021 yılında Dota2 234.775.181,17 \$’lık ödül havuzu ile şu ana kadar 1525 tane turnuva düzenleyerek birinci sırada yer almaktadır.

Turizm, doğal çevresel ve kültürel kaynaklara yoğun olarak ihtiyaç duyan ve bunları ekonomik girdi olarak kullanan bir endüstridir (Çalışkanyol, 2020). Dijital oyunların gün geçtikçe popülaritesinin artış göstermesi ve bu sektörün turizminin yardımıyla günümüz dönemindeki özellikle genç nesil için bir motivasyon kaynağı olarak görülmektedir. E-Spor turnuvaları, spor turizmi ve turistik aktivite kapsamında değerlendirildiğinde; yüksek maliyetli yatırımlar, zahmetli organizasyon gereklilikleri ve ev sahipliği hakkı kazanmanın zorluğu düşünüldüğünde şehrin ismini duyurma ve turist çekme açısından önem arz etmektedir (Gül, Kızılırmak, Güler ve Erhan, 2017). 
Bulut Ç, Duman S, Şahin HM, Duman G, Uluç EA. (2021). Spor Turizminde İnovasyonel Yaklaşımlar: E-Spor. Gaziantep Üniversitesi Spor Bilimleri Dergisi, 6(4), 396-412.

Yeşil (2015)'e göre, turizmin bir alt dalı olan spor turizmi ile ilgili yapılan tanımlar incelendiğinde; spor turizmi kapsamı içerisinde, katılımcıların sportif ya da ticari bir etkinliği gerçekleştirmek için bulunulacak olan bölgede 24 saati geçmeme gibi bir süre sınırlamasının bulunmaması, turizm ve spor turizmi arasındaki temel farktır.

Öztürk ve Yazıcıoğlu (2002)'e göre, spor turizmi gerek uluslararası gerekse de ulusal düzeyde gerçekleştirilecek olan sportif organizasyonlar, turlar ya da şampiyonalara katılım sağlayan bireylerin, serbest zamanları değerlendirme ya da mücadele etme intiyacından doğan turizm hareketi olarak tanımlanmaktadır. Bu açıdan incelendiğinde, E-Sporun spor turizmi kapsamında değerlendirilmesi yapılan bu araştırmanın amacını oluşturmaktadır.

\section{Turizm}

Dünya Turizm örgütüne göre Turizm; insanların dinlenme, eğlenme, çalışma ve diğer gayelerle sabit kaldıkları mekânların ötesine kazanç sağlama amacı içindeki eylemlere bağlı olmaksızın ve bir yıldan fazla uzun sürmeyecek biçimde gezintiye çıkmalarından ve konaklamalarından meydana gelen etkinliklerdir (Çuhadar, 2006).

Turizm kavramları sözlüğünde turizm, "asıl yaşadığı yerin dışındaki farklı bir yere eğlenme, tatil, kültür, arkadaş veya akraba ziyareti, spor yapma, konferans, görev, eğitim, sağıı, transit geçiş vb. amaçlarla seyahat etmenin ortaya çıkardığı olayların tümü” olarak tanımlanmaktadır (T.C Turizm Bakanlığı, 1999).

Nations World Tourism Organization (UNWTO) turizmin vakit etmenini ileri sürerek toplulukta bulunan fertlerin zamanın büyük çoğunluğunu geçirdikleri memleketlerin ötesine yolculuğa çıkmaları ve bu gezintinin minimum bir günden az, maksimum bir yıldan çok olmamak kaydı ile türlü sebeplerden ötürü gerçekleştirdikleri etkinliklerin tümüdür şeklinde tanımlamıştır (Akt; Karaman, 2016).

Turizm ile ilgili açıklamalar, tanımlamalar gösteriyor ki, turizm geçmişten günümüze insanların yoğun çalışma hayatlarından kalan zamanda aktif veya pasif olarak dinlenmek, eğlenmek, doğa harikası yerleri görmek, hoşça vakit geçirmek için bulundukları yerlerden kısa süreliğine de olsa başka diyarlara yolculuk etmeleri ve o diyarların kültürünü geleneğini, yaşam biçimlerini öğrenip haz almalarını sağlayan faaliyetler bütünüdür (Özdemir, 2020).

\section{Turizmin Önemi}

Turizm, ülkelerin ekonomik, toplumsal ve kültürel yaşam tarzlarını olumlu yönde etkilemektedir. Turgut (2019)'a göre, özellikle genç nüfusa sahip ülkelerde istihdam alanı yaratmış, yerli ve yabancı turistlere sunduğu cazip tekliflerle ülke ekonomisine 
Bulut Ç, Duman S, Şahin HM, Duman G, Uluç EA. (2021). Spor Turizminde İnovasyonel Yaklaşımlar: E-Spor. Gaziantep Üniversitesi Spor Bilimleri Dergisi, 6(4), 396-412.

kayda değer katkılar sunmaktadır. Küresel açıdan turizm kazançlarının artış göstermesi, o ülkenin gelişmişlik düzeylerinden, ülke içerisinde yaşayan insanlarına yaşam tarzlarına kadar etki etmektedir. Ayrıca I. Dünya ülkelerinde çalışma sürelerinin kısalması, serbest zaman etkinliklerinin artması, iletişimin ve ulaşımın kolaylaşması, cazip tur paketlerinin müşterilere sunulması; aynı zamanda insanların başka diyarları gezmek ve o ülkelerin geleneklerini tanımak istemeleri gibi etkenler turizmin gelişmesinde, hız kazanmasında etkili olmaktadır (Usta, 2009).

\section{Spor Turizmi}

Turizm ve spor kavramları, sporun dünyada çok geniş bir kitleye hitap etmesi, sosyal yaşantının gelişmesiyle birlikte her geçen gün bir talep artışı yaşanmakta ve önem derecesi yükselmektedir, spor turizmi ve spor turizm pazarlaması beraberinde oluşmaktadır. Böylelikle spor turizmi aktivite tanımını beraberinde getirmekte ve insanların faaliyetleri olarak değerlendirilmektedir. Çalışkan (2018)'a göre, spor turizmi insanların yeryüzünün eşi olmayan sosyokültürel ve ekonomik bir oluşumunu meydana gelmektedir. Gibson (1998)'e göre, spor alanlarının ziyaret edilmesi ve spor etkinlilerinin izlenmesi pasif turizm içerisinde yer alırken, sportif bir etkinliğe katılım sağlamak amacıyla yapılan seyahatler aktif turizm içerisinde yer almaktadır. Bir başka tanıma göre ise, spor ile ilgili faaliyetlere katılmak için seyahat eden turistlerin oluşturduğu turizm türüdür (Türkiye Seyahat Acentaları Birliği, 2014). Yine spor turizmi, aktif ve pasif katılımlı bütün spor aktivitelerinde, tesadüfen katılımlarda veya planlanmış katılımlarda veya ticari olan ya da olmayan sebepli katılımda evden ya da işten yapılan seyahati kapsar şeklinde tanımlanmıştır (Alpullu, 2011). Kısacası, spor turizmini amatör veya profesyonel olarak bir sportif faaliyeti gerçekleştirmek, herhangi bir spor organizasyonunu seyirci olarak takip etmek veya sportif değeri olan turistik noktaları (müze, stadyum vb.) ziyaret etmek amacıyla yapılan seyahatler olarak tanımlamak mümkündür (Güdük, 2019). Yukarıdaki yapılan tanımlamalar incelendiğinde spor turizminin üç farklı amaçla yapıldığı görülmektedir. Bunlardan ilki spor yapmak amacıyla spor turizmin kullanılması, ikincisi, spor müsabakaların izlenmesi, son olarak da turistik noktaların ziyaret edilmesini kapsamaktadır.

\section{Spor Turizmi ve Ekonomi}

Spor etkinlikleri aracılığıyla ortaya çıkacak turizm; düzenleyen ülke için döviz girdisi açısından mühim bir faktör olduğu kadar bölgeler arası eşitsizliği önleme açısından da son derece önemli etkisi bulunmaktadır (Özdemir, 2020). Buna ilaveten gelişmekte olan ülkelerde yeni iş kollarının açılmasına, altyapı, ulaşım, iletişim gibi 
Bulut Ç, Duman S, Şahin HM, Duman G, Uluç EA. (2021). Spor Turizminde İnovasyonel Yaklaşımlar: E-Spor. Gaziantep Üniversitesi Spor Bilimleri Dergisi, 6(4), 396-412.

alanların daha ileri seviyelere ulaşmasında önemli katkı sağlayacağı öngörülmektedir (İçöz ve Kozak, 2002). Spor turizminin iktisadi etkileri; yerel ve küresel organizasyonlar sayesinde dünyanın her bir köşesinden önemli iş insanlarını, gazetecileri, sporcuları ve sporseverleri bir araya getirmekte, yaptıkları harcamalar sayesinde ülkeye döviz girdisi olmakta ve ülkenin tanıtımında etkin rol oynamaktadırlar (Şebin, 2018).

Spor turizminin ekonomik etkileri turizmde en önemli faktör olarak görülmektedir. Spor turizminin kâr getirici özelliğinin olması, iş alanlarının çoğalması ile ülkeler arasında ticari ilişkilerin artması gibi pek çok olumlu etkileri bulunmaktadır (Ross, 2001). Özellikle küresel çapta etkiye sahip olan spor organizasyonlarının spor turizmi içerisindeki etkisiyle organizasyonu düzenleyen ülkenin tanıtımında, ekonomik kalkınmasında, istihdam alanlarının yaratımasında, ticari faaliyetlerinde, spora olan ilginin artmasında, ülkenin saygınlık kazanmasında etkili olacağı kamuoyu tarafından bilinmekte ve bundan dolayı ülkeler arasında bu tür organizasyonlara ev sahibi olabilmek için kıyasıya bir yarışın içerisine girilmektedir (Gündoğdu, 2001).

\section{E-Spor}

Teknoloji alanında meydana gelen gelişmeler her alanı etkilediği gibi spor alanlarını da etkilemiş, bu durum beraberinde spor ve sporcu kavramlarını değişikliğe uğratarak spor alanlarına birçok yeni branş eklenmesine olanak tanımıştır (Kocadağ, 2017). Teknolojik gelişmeler ışığında değişen ve dönüşen dallardan birisi de spordur (Akgöl, 2019). Spor alanı ile ilgili yeni alt dallar, kurallar, yenilenmiş ya da değişikliğe uğramıştır. (Aslan, 2019).

Spor alanına yeni eklenen branşlardan birisi de E-Spordur. Spor bireysel ya da takım halinde yapılan, kendi içerisinde belirli kuralları bulunan, genellikle yarışmaya dayalı ve buna bağlı olarak içerisinde mücadele unsuru barındıran, bireyin fiziksel ve zihinsel gelişimini sağlayan eğlendirici ve öğretici etkinliklerin tümü olarak tanımlanabilir (Atasoy ve Kuter, 2005). E-Spor elektronik sistemler aracılığı ile sporun temel özelliklerinin basite indirgenmesiyle, uygulanan bir spor biçimidir (Albayrak, 2019). Çevrimiçi ya da çevrimdışı bir şekilde oynanan E-Spor oyunlarının temeli rekabetçi oyunlara dayanmaktadır (Aslan, 2019). E-Spor, ilk bilgisayar oyunları ile varlığını elde etmiş, ancak 6-7 yıldır popülerlik kazanmış olan bir kavramdır (Kocadağ, 2017). 2008 yılında uluslararası E-Spor federasyonunun kurulmasıyla birlikte E-Spor dünya çapında spor olarak görülmeye başlanmıştır. Competitive Gaming (rekabetçi oyun) E-Sporun küresel düzeyde bilinen ismidir (Kocadağ, 2017). Günümüzde E-Spor alanında birçok turnuvalar E-Spor arenalarında düzenleniyor ve E-Sporcular kendi 
Bulut Ç, Duman S, Şahin HM, Duman G, Uluç EA. (2021). Spor Turizminde İnovasyonel Yaklaşımlar: E-Spor. Gaziantep Üniversitesi Spor Bilimleri Dergisi, 6(4), 396-412.

bilgisayar ekranlarında, takım arkadaşları ile beraber oyun oynamakta, bu oyunlar ise büyük bir ekran aracılığı ile sayısı binleri bulan seyircilere paylaşımaktadır (Snavely, 2014). Z $Z$ ve $Y$ kuşağı olarak adlandırılan gençler tarafından E-Spor yaşamın bir parçası olarak görülmekte ve bu gençler fiziksel sınırlarının dışında neler yapabileceklerinin farkında olmaktadırlar (Gider, 2019). Böylelikle internet bağlantıları aracılığı ile bir araya gelen oyuncular oyun platformlarında birbirileri ile rekabet etmektedirler.

\section{Dünyada ve Türkiye'de E-Sporun Gelişimi}

1990'ı yıllarda ortaya çıkmaya başlamış olan E-Spor kavramının gelişiminde iki ana unsur etkilidir (Wagner, 2006; Hartmann ve Klimmt, 2006). Bu unsurlardan ilki bilgisayar oyunlarının popülaritesinin ve tüketici okur yazarlığı sayısında meydana gelen artış olarak gösterilirken, dijital teknolojinin ve internet lanında meydana gelişim ikinci unsur olarak ifade edilmektedir (Seo, 2013). E-Spor etkinliklerinin organize olmuş hali 1980'li yıllara dayanmaktadır. Bu dönemlerde E-Spor etkinlikleri Üniversite kampüslerinde de yer almaya başlamıştır. 10.000'den fazla yarışmacı katııımcısı olan ilk video oyun yarışması Atari'nin Space Invaders adlı oyunudur (Yımaz, 2020). 1997 yılında ise E-Spor ile ilgili yarı profesyonel ve profesyonel düzeyde oyun ligleri oluşturulmuştur (Seo, 2013).

Yılmaz (2020)'a göre, Güney Kore'de internet alt yapılarda meydana gelen gelişmeyle 1999 yılında Star Craft isimli oyun Blizzard Şirketi tarafından tanıtılmış ve bu şirket tanıtılan oyun sayesinde hızlıca büyümeye başlamıştır. Seo (2013)'e göre, Rekamet içerikli video oyunlarını piyasaya süren Blizzard Entertainment şirketi Kore'den sonra Asya pazarına da hakim olmuştur. Ayar (2018)'e göre, Çevrimiçi Oyuncular Derneği (Online Gamers Association)'nin 1999 yılındaki bir basin bültenin E-Spor terimi kullanıımıştır. Böyelikle E-Spor yayılmaya başlamışı̧ı. Peichi (2008)'e göre, E-Sporun yaygılaştırıması için yalnızca genç ve yetişkin yaş guruplarına özel olarak bilgilsayar oyunlarının içerikleri bazı televizyon kanallarında yayınlanmıştır. Üçüncüoğlu ve Çakır (2017)'e göre 2000'li yıllarda "Electronic Sports League" kurulmuştır. Electronic Sports League'in kurulumu E-Spor'un profesyonelleşmesi adına kaydedilen önemli bir gelişme olarak görülmektedir. Ayrıca 2008 yılında kurulan Uluslararası E-Spor Federasyonunun kurulmasıyla, E-Spor artık bir spor olarak kabul edilmeye başlanmıştır. Riot Games tarafından 2011 piyasaya sürülen League of Legends (LoL) isimli oyun, piyasaya sürüldügün günün yarısında 30.000 oyuncu bu oyun için kaydolmuştur (Yılmaz, 2020). Lee ve diğerleri (2014)'ne göre, 2013 yılında 
Bulut Ç, Duman S, Şahin HM, Duman G, Uluç EA. (2021). Spor Turizminde İnovasyonel Yaklaşımlar: E-Spor. Gaziantep Üniversitesi Spor Bilimleri Dergisi, 6(4), 396-412.

League of Legends (LoL) isimli oyunun toplam çevrimiçi kullanım süresi \%37,19'a ulaşmıştır. Seo (2013)'e göre, E-Spor oyunlarının denetlenebilmesi için, ulusal ve uluslarası yönetim organları kurulmuştur. Akademik yaşamda da E-Spor rüzgârı esmiştir. 2014 Temmuz'da Robert Morris Üniversitesi E-Sporu Atletizm Bölümü tarafından destekleyip bir çeşitlilik sporu olarak tanıyan ve burs veren ilk üniversite olmuştur. Aynı yılın aralık ayında ise Pikeville Üniversitesi E-Sporu resmi bir üniversite spor takımı yapan ikinci üniversite olmuştur (Jenny, Manning, Keiper ve Olrich, 2017; Funk, Pizzo ve Baker, 2019). Malezya ve Çin'de DOTA2 oyun kursu vermeye başlamış üniversiteler bulunmaktadır (Kocadağ, 2017).

Türkiye'de ise Bahçeşehir Üniversitesi tarafından ulusal ve uluslararası düzeyde E-Spor faaliyetlerine katkı sağlamak amacıyla 2016 yılında E-Spor organizasyonu kurulmuştur. 2017-2018 eğitim öğretim yılı güz dönemi itibariyle de League of Legends Türkiye Şampiyonluk ve Yükselme liglerinde başarı gösteren öğrencilere E-Spor bursu veren ilk üniversite olmuştur (Bahçeşehir Üniversitesi ESpor). Ayrıca İstanbul Bilgi Üniversitesi ise "Playerbros" lig turnuvasında birinci olan lise öğrencilerinin, üniversite sınavları sonunda İstanbul Bilgi Üniversitesi İletişim Fakültesi'ni kazanmaları durumunda \%100 burs sağlamaktadır (Üçhisarlı, 2017).

24 Nisan 2018 tarihinde Gençlik ve Spor Bakanlığı, Spor Genel Müdürlüğü'ne bağlı olarak Türkiye E-Spor Federasyonu (TESFED) Başkanlığı kurulmuştur (Yılmaz, 2020). Federasyon, Türkiye'deki E-Spor faaliyetlerinin artmasını, dünyada kabul görmesini sağlamak amacını gütmektedir. Ayrıca E-Spor federasyonu oyunculara lisans vererek, resmi turnuvalarda yarışmalarına olanak sağlamış ve E-Spor alanına ilişkin önemli bir adım atmıştır (Gençlik ve Spor Bakanlığı E-Spor Raporu, 2018).

\section{E-Spor ve İzleyici Kitlesi}

Her spor dalında olduğu gibi E-Sporda da profesyonel ve amatör sporcular bulunmakta, (Evren, Kargün, Pala ve Yazarer, 2019) ve her spor dalında olduğu gibi E-Sporda da müsabaka ve yarışmalar bulunmaktadır (Mustafaoğlu, Zirek ve Yasacı, 2018). E-Spor profesyonel liglere katılım sağlayan profesyonel oyunculardan oluşmaktadır (Fanatik, 2017). Profesyonel liglere katııım sağlayan bu sporcular, belirli ödüller elde etmektedirler. Ayrıca Dijital oyunların her geçen gün artması ve gelişmesiyle birlikte E-Spor, üretici ve katılımcıları arasında rekabeti daha da güçlendirmektedir (Atalay ve Boztepe, 2020).

Akgöl (2019)'e göre; E-Spor ekosisteminin bir diğer değerli parçası da seyircilerdir. Genç ve dinamik bir seyirci kitlesine sahip olan E-Spor, bir nevi bu kitlenin 
içerisinden çıkmış bir alandır. Öyle ki çok eski tarihlerde atari salonlarında başlayan, devamında konsol oyunlarının çeşitlenmesiyle evlere giren ve en sonunda internetin yaygınlaşmasıyla şimdiki halini alan E-Spor, sahip olduğu tüm özellikleri seyircilerinden ve amatör olarak oyunlara gönül veren kişilerden almıştır. Aynı ekosistem içerisinde yoğrulan bu kitle, E-Sporun yaygınlaşmasında büyük bir pay sahibi olmuştur. 2016 yılında 121 milyon E-Spor taraftarı bulunurken, bu oran 2017 yılında 143 milyon, 2018 yılında ise; 165 milyona ulaşmış, bu durum 2021 yılı içi değerlendirildiğinde ise E-Spor alanında toplam izleyici oranı \%14,4 oranında bir büyüme göstererek 250 milyona ulaşacağı tahmin edilmektedir.

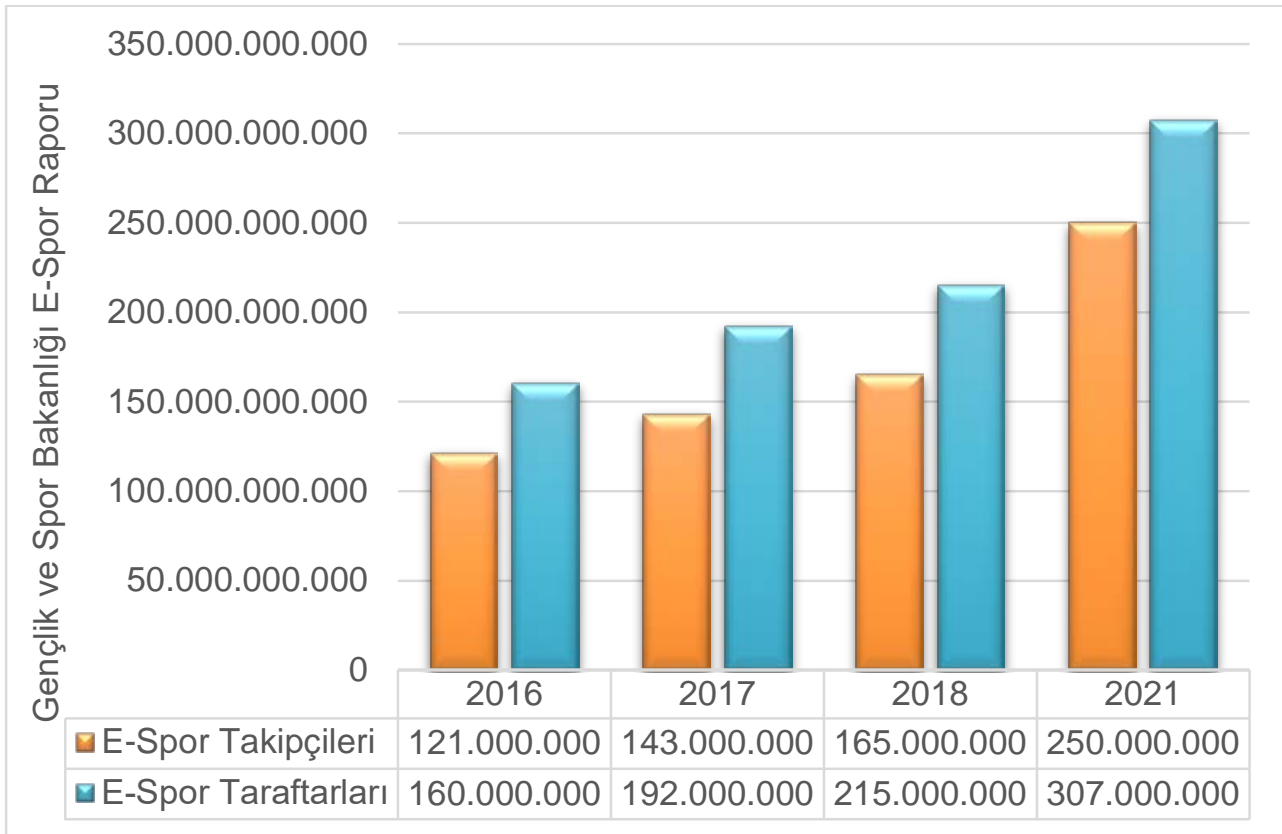

Şekil 1. E-Spor Takiçilerinin Oranı

Kaynak: Gençlik ve Spor Bakanlığı E-Spor Raporu (2018).

Yukarıdaki grafiğe göre E-Spor takipçilerinin oranı değerlendirildiğinde; 2016 yılında 160 milyona ulaşan E-Spor takipçileri oranı, 2017 yılında 192 milyona \%5,5 oranında bir büyüme göstermiş, geçen yıllara oranla toplam izleyici sayısı, \%19,3 bir büyüme kaydetmiş, 2018 yılında ise bu oran, 215 milyona ulaşmıştır. Bu durum 2021 yılına göre değerlendirildiğinde ise; bu rakamın 307 milyona ulaşarak beklenen büyüme oranının yılda \%25 olacağı öngörülmektedir.

Pişkin ve diğerleri (2019)'ne göre, E-Sporda hayran kitlelerinin yaş oranları şu şekildedir; 


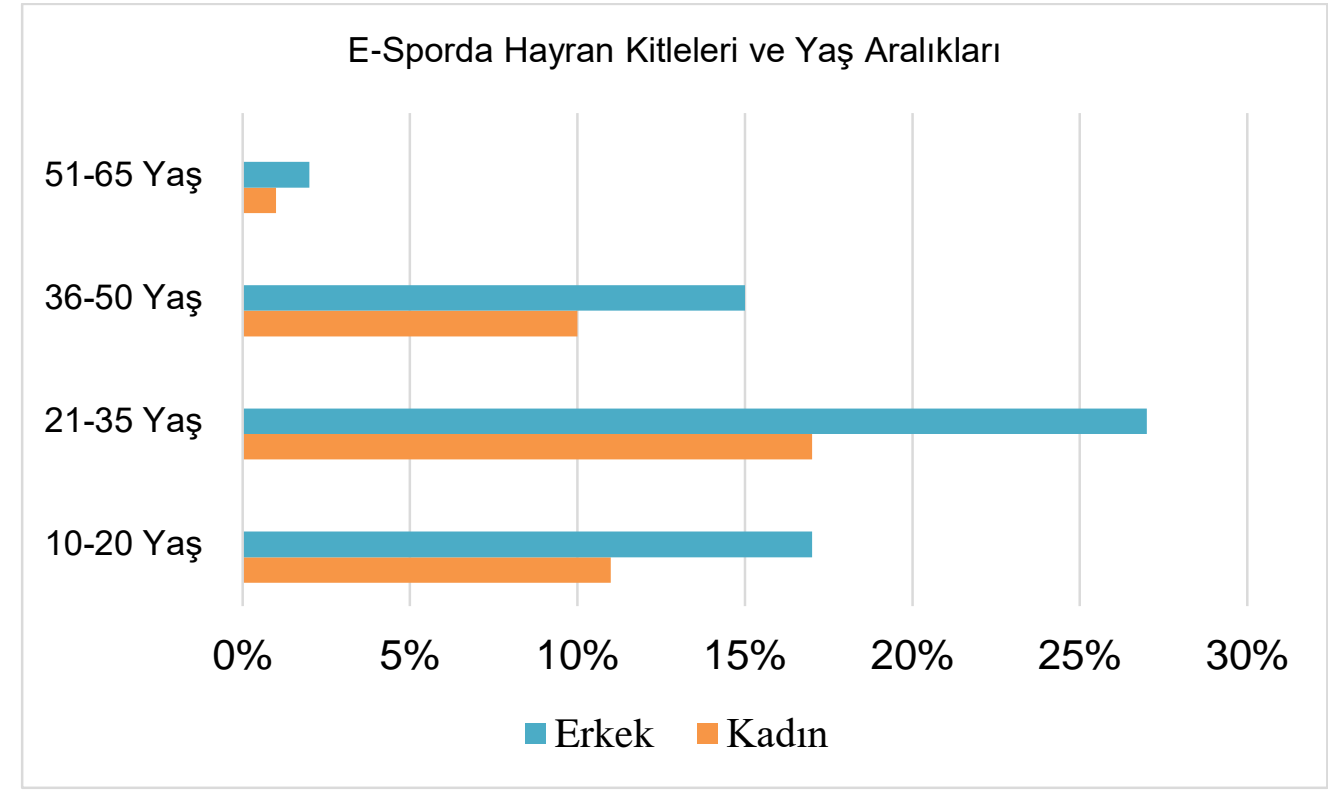

Şekil 2. E-Spor Hayran Kitleleri ve Yaş Aralıkları

Kaynak: Pişkin, Devecioğlu ve Halisdemir (2019).

Pişkin ve diğerleri (2019)' ne göre, E-Spor taraftarlarının yaş oranları incelendiğinde; erkek takipçilerinin \%27'sinin 21- 35 yaş aralığında, kadın takipçilerinin ise; \%17 oranında 21-35 yaş aralığında olduğu sonucuna ulaşılmıştır. Yukarıdaki tablodan anlaşılacağı üzere E-Spor taraftarlarının \%61'i erkek takipçiler tarafından oluşmaktadır. En yüksek E-Spor takipçisi oranının her iki cinsiyet grubunda da 21-35 yaş aralığında olması dikkat çekici bir durumdur. Bu veriler Türkiye'de erkeklerin oyunlar ile tanışma zamanlarının ilkokul yıllarına kadar uzadığını, kadınların ise lise yıllarından itibaren tanışı̆̆ı sonucunu ortaya koymaktadır. E-Spora erkeklerin kadınlardan daha önce başladığı ve E-Spora daha önceden aşina oldukları söylenilebilir (Twentify, 2018).

Gençlik ve Spor Bakanlığının E-Spor raporu (2018)'na göre, E-Spor alanında en çok kazanç elde elden ülkelerin sıralamaları ise şöyledir; 


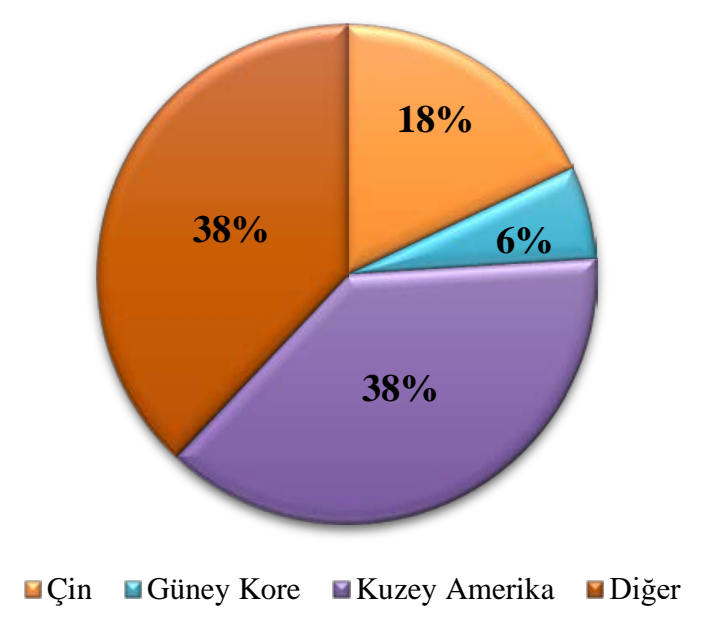

Kaynak: Gençlik ve Spor Bakanlığı E-Spor Raporu (2018)

Gençlik ve Spor Bakanlığı (2018)'e göre, en çok gelir elden ülkeler incelendiğinde; Çin ve Kuzey Amerika'nın 2018 yılında 509 milyon dolarla küresel ESpor gelirlerinin \%56'sını oluşturduğu görülmektedir (Pişkin ve diğerleri, 2019). Kuzey Amerika'nın tek başına \%38'lik bir gelir düzeyi elde etmesi dikkat çekici bir orandır. Diğer ülkeler olarak adlandırılan birçok ülkenin bir araya getirilmesiyle \%38'lik oranda oluşan rakama Kuzey Amerika'nın tek başına erişmiş olması da ayrıca kayda değer bir göstergedir.

İnternational E-Sports Federation 'a göre, 2009 ve 2021 yılları arasında yapılan E-Spor dünya şampiyonaları şu şekildedir.

\begin{tabular}{|l|l|l|l|}
\hline \multicolumn{1}{|c|}{ Yıl } & Ev sahibi Şehir & $\begin{array}{c}\text { Katılım sağlayan E- } \\
\text { Sporcu Sayısı }\end{array}$ & Kazanan Ülke \\
\hline $\mathbf{2 0 0 9}$ & Taebaek & 180 & Güney Kore \\
\hline $\mathbf{2 0 1 0}$ & Daegu & 250 & Güney Kore \\
\hline $\mathbf{2 0 1 1}$ & Andong & 300 & İsveç \\
\hline $\mathbf{2 0 1 2}$ & Cheonan & 300 & Güney Kore \\
\hline $\mathbf{2 0 1 3}$ & Bükreş & 350 & Güney Kore \\
\hline $\mathbf{2 0 1 4}$ & Bakü & 400 & Güney Kore \\
\hline $\mathbf{2 0 1 5}$ & Seul & 400 & Sırbistan \\
\hline $\mathbf{2 0 1 6}$ & Cakarta & 400 & Güney Kore \\
\hline $\mathbf{2 0 1 7}$ & Busan & 400 & Güney Kore \\
\hline $\mathbf{2 0 1 8}$ & Kaohsiung & 400 & Güney Kore \\
\hline $\mathbf{2 0 1 9}$ & Seul & 400 & Japonya \\
\hline $\mathbf{2 0 2 1}$ & Eilat, Israil & - & - \\
\hline
\end{tabular}

Kaynak: İnternational E-Sports Federation (2021)

\section{E-Sporun Spor Turizmi Açısından Önemi}

Insomnia İngiltere'de düzenlenen E-Spor festivallerinden birisi olarak bilinmektedir. İngiltere'de düzenlenen bu festivale dünyanın birçok yerinden E-Spor 
Bulut Ç, Duman S, Şahin HM, Duman G, Uluç EA. (2021). Spor Turizminde İnovasyonel Yaklaşımlar: E-Spor. Gaziantep Üniversitesi Spor Bilimleri Dergisi, 6(4), 396-412.

taraftarı ve sporcuları katıım sağlamaktadır. İnsomnia festivali farklı niteliklerde konaklama imkanları, oyun sonrası eğlenceler ve birçok turistik aktiveleri yapısı içerisinde bulundurulmaktadır (Bayram, 2018).

Epic Games tarafından düzenlenen EPIC 23 turnuvası 3 gün boyunca süren bir E-Spor festivalidir. Festivale katııım sağlayan seyirciler için bu turnuvada, oyun öncesi etkinlikler ve oyun sonrası partiler düzenlenmiştir. Malin (2018)'e göre E-Spor açısından spor turizmi büyük bir gelişme göstermektedir. Spor turizmi açısından ESpor düşünüldüğünde; ülkenin tanıtımı, ziyaretçi sayısının artış göstermesi, destinasyonun markalaşma açısından büyük bir öneme sahiptir. E-Spor aktivitelerinin belirlenmiş bir ülkede ve destinasyonda, turnuvalar şeklinde gerçekleştirilmesi, bu turnuvalara oyuncuların, izleyicilerin, ilgili kurum ve kuruluşların katılması, yeme, içme, konaklama, eğlenme gibi çeşitli turistik aktiviteleri kullanmasına dayanan turizm türü olarak tanımlamak mümkündür (Bayram, 2018).

Elsgaming (2014)'e göre, E-Sporun turistik bir aktivite olarak kabul edilmesindeki bazı sebepler şu şekildedir;

1. E-Spor turnuvalarının düzenlendiği alanda izlenmesi katııımcılar açısında muazzam bir deneyim fırsatı sunmaktadır.

2. Dünya liginde yarışan sporcular ile E-Spor taraftarlarının karşılaşma imkânı bulunmaktadır.

3. E-Spor taraftarı, E-Sporcu ile aynı hissi ve aynı amacı taşımaktadır. Böylelikle izleyici sporcu ile aynı mücadele içerisinde yer almaktadır.

4. Düzenlenen E-Spor turnuvaları, düzenlendiği bölgenin turistik açıdan potansiyeli arttıracaktır.

\section{Tartışma ve Sonuç}

Spor turizmi kapsamında E-Sporun değerlendirildiği bu araştırma bizlere bu konuda yapılan araştırmaların oldukça az sayıda olduğunu göstermiştir.

Keçeci ve Çelik (2021)'e göre, E-Spor sporun yeni bir formu olarak ortaya çıkmış ve son yıllardaki popülaritesiyle de dikkat çekici bir branş olmayı başarmıştır. Koç (2021)'e göre, ise dünyada yoğun ilgi gören E-Spor, Türkiye'de de sayıca büyük bir kullanıcı kitlesi yakalamayı başarmıştır. Aktuna ve Ünlüönen (2017)'e göre, çevrimdışı olarak fiziksel bir mekânda düzenlenen bilgisayar oyunları turnuvalarına katılan profesyonel takımların, seyircilerin ve turnuva düzenleyicilerinin oluşturduğu etkileşim açısından ESpor spor turizmi kapsamında değerlendirilebilmektedir. 
Bulut Ç, Duman S, Şahin HM, Duman G, Uluç EA. (2021). Spor Turizminde İnovasyonel Yaklaşımlar: E-Spor. Gaziantep Üniversitesi Spor Bilimleri Dergisi, 6(4), 396-412.

Newzoo şirketi 2020 yılına ait "Küresel E-Spor Endüstri Raporunu" şubat ayı içerisinde yayımlamıştır. E-Spor ekonomisine ilişkin tüm finansal verilerin paylaşıldığı 2020 yılı raporunda E-Spor endüstrisine ilişkin ekonomik ve ticari gelişim ve ilerlemeler şu şekilde özetlenmiştir. Buna göre; küresel E-Spor ekonomisinin gelirleri ilk kez bir milyar doların üstüne çıkarak toplamda 1,1 milyar dolara ulaşmıştır. 2019 yılı toplam geliri 950,6 milyon dolar seviyelerinde idi. Son bir yılda yaklaşık 50 milyon dolarlık bir artış görülmüştür. Ifade edilen 1,1 milyar dolarlık toplam gelir içerisinde en büyük gelir kaynağı 822,4 milyon dolar ile medya hakları ve sponsorluk gelirleri olarak kaydedilmiştir. Medya ve sponsorluk gelirlerinin 2023 yılında tek başına 1,2 milyar dolara ulaşması öngörülmektedir. 2020 yılında toplam seyirci sayısı 495 milyon kişiye ulaşmıştır. Geçtiğimiz 2019 yılı sonu itibari ile 885 büyük organizasyon düzenlenmiş ve bu organizasyonlarda toplamda 56,3 milyon dolar bilet geliri elde edilmiştir. Bu kadar çok etkinliğin düzenlendiği ve kişinin ilgilendiği bu spor dalının turizm açısından incelenmesi önem arz etmektedir.

Bayram (2018)'a göre, E-Sporun ülke ve bölge turizmine pek çok katkısı olduğunu söylemek mümkündür. E-Spor turistik açıdan gelişmiş ülkelerin ekonomilerine büyük girdiler sağlamakta, var olan imajlarını güçlendirmekte, kayda değer bir tutundurma aracı olarak görülmektedir. E-Spor kapsamında düzenlenen turnuvalar spor turizmi açısından incelendiğinde; düzenlenen organizasyonlara aktif ya da pasif katııım sağlayan kişinin beraberinde düşünce, fikir, yenilik ve para getirirken, karşı taraftan da beklentileri bulunmaktadır. Bu beklentiler beslenme, barınma, eğlenme şeklinde sıralanabilir. Ayrıca spor organizasyonlarının oluşturduğu hizmetlerde çeşitli iş olanaklarının ortaya çıkması belirli kişiler tarafında olumlu bir etki olarak ifade edilirken, bir kııı için de toplumsal sorunların ortaya çıkması, çevre sorunlarının meydana gelmesi gibi olumsuz etkilerin toplumsal yapı üzerinde olumsuz etkilere neden olan faaliyetler olarak görülmektedir (Öziş, 2017). E-Sporda düzenlenen turnuvalar da sporcuların belirli bir destinasyonda konaklama süreleri 10 güne kadar çıkabilmektedir. Düzenlenen büyük turnuvalara katılım sağlayan sporcular açısından spor turizmi değerlendirildiğinde; her takım içerisinde yer alan sporcular turnuva için bulundukları destinasyonda turist olarak değerlendirilmektedir. Ayrıca turnuvayı izlemek amacıyla gelen seyirciler düzenlenen turnuva açısından düşünüldüğünde belirli bir turistik faaliyetin içinde yer almaktadırlar. Dolayısıyla, bu durum gerek spor yapan açısından gerekse seyirci ya da taraftar açısından destinasyon için bir turist kaynağı olarak görülmektedir. Ayrıca E-Spor için düzenlenen turnuvalar ülkelerin 
Bulut Ç, Duman S, Şahin HM, Duman G, Uluç EA. (2021). Spor Turizminde İnovasyonel Yaklaşımlar: E-Spor. Gaziantep Üniversitesi Spor Bilimleri Dergisi, 6(4), 396-412.

imajlarına da olumlu yönde katkılar sağlayabilmektedir. Elde edilen bu sonuçtan harekete; Türkiyede düzenlenen E-Spor turnuvalarının sayısının arttırılması önerilmektedir.

\section{Kaynaklar}

Akgöl, O. (2019). Spor Endüstrisi ve Dijitalleşme: Türkiye'deki Espor Yapılanması Üzerine Bir İnceleme. TRT Akademi, 4(8), 206-224.

Aktuna, H. C. ve Ünlüönen, K. (2017). Yeni bir turizm çeşidi olarak elektronik spor turizmi. Gazi Üniversitesi Turizm Fakültesi Dergisi, (2), 1-15.

Albayrak, O. ve Arabacıoğlu, B. C. (2020). E-Spor turnuva mekânlarının mekânsal anlamının oyun-insan-mekân etkileşimi bağlamında yorumlanması. bab Journal of FSMVU Faculty of Architecture and Design. 1 (2), s. 228-243.

Alioğlu, M. ve Algül, A. (2021). Türkiye'de Dijital Oyun Durumu: E-Spor Oyuncularının Değerlendirmeleriyle League of Legends Örneği. İstanbul Aydın Üniversitesi Sosyal Bilimler Dergisi, 13(1), 121-154.

Alpullu, A. (2011). Uluslararası Basketbol Organizasyonlarının Spor Turizmine, Ekonomisine ve Tanıtımına Katkılarının Değerlendirilmesi. Yayımlanmamış Doktora Tezi, Marmara Üniversitesi, İstanbul.

Aslan, T. (2019). Akademik ve Yönetsel Bakış Açısıyla Espor. Yayımlanmamış Yüksek Lisans Tezi, Bolu Abant Üniversitesi, Sosyal Bilimler Enstitüsü, Spor Yöneticiliği Anabilim Dalı, Spor Yöneticiliği, Bilim Dalı, Bolu.

Atalay, A. ve Boztepe, E. (2020). An evaluation on e-sports industry and its economic outputs. Journal of Accounting, Finance and Auditing Studies, 6(3)

Atasoy, B. ve Kuter, F. Ö. (2005). Küreselleşme ve spor. Uludağ Üniversitesi Eğitim Fakültesi Dergisi, 18(1), 11-22.

Ayar, H. (2018). Development of e-Sport in Turkey and in the World. International Journal of Science Culture and Sport, 6(1).

Bahçeşehir Üniversitesi E-Spor. Erişim Adresi BAU eSports Erişim Tarihi 07.07.2021. Bayram, A. T. (2018). Planlanmış Davranış Teorisi Çerçevesinde E-Spor Turizmine Katılma Niyeti. Turizm Akademik Dergisi, 5(2), 17-31.

Bingöl, H., Bingöl, Ş. ve Öner, İ. (2021). Covid-19'un E-Spor Sektörü Üzerindeki Etkisi. Journal of ROL Sport Sciences Volume, 2(1).

Çalışkan, A. (2018). Kişileri Ultra Maraton Koşmaya Motive Eden Faktörler Ölçeğinin Geliştirilmesi ve Bu Faktörlerin Katıımcıların Yaşam Doyumları ve Başarı 
Algılarıyla Karşılaştırılması. Yayımlanmış Yüksek Lisans Tezi, Akdeniz Üniversitesi, Antalya.

Çalışkanyol, C. (2020). Dijital Oyunların ve E-Sporun Coğrafi Açıdan Değerlendirilmesi: Istanbul. Örneği. Yayımlanmamış Yüksek Lisans Tezi, Çanakkale Onsekiz Mart Üniversitesi, Coğrafya Anabilim Dalı, Çanakkale.

Çuhadar, M. (2006). Turizm Sektöründe Talep Tahmini Için Yapay Sinir Ağları Kullanımı ve Diğer Yöntemlerle Karşılaştırmalı Analizi (Antalya Ilinin Dış Turizm Talebinde Uygulama). Yayımlanmamış Doktora Tezi, Süleyman Demirel Üniversitesi, Isparta.

Durak, E. (2020). Türkiye'de Espor Takımları Erişim Adresi https:// technotoday.com.tr/turkiyede- espor-takimlari/ Erişim Tarihi 08.07.2021.

Elsgaming A. (2014). The growth and future of esports tourism. Erişim Adresi https:// www.eslgaming.com/article/growth-and-futureesports-tourism-1565. Erişim Tarihi 08.07.2021.

Evren, T., Kargün, M., Pala, A.ve Yazarer, İ. (2019). Spora Yenilikçi Yaklaşım: E-Spor. Journal of International Social Research, 12(66).

Fanatik (2017). Espor nedir? Bora Koçyiğit Fanatik'e anlattı! Erişim Adresi https://www.fanatik.com.tr/espor-nedir-bora-kocyigit-fanatik-e-anlatti-1286961 Erişim Tarihi 08.07.2021

Funk, D. C., Pizzo, A. D. ve Baker, B. J. (2019). eSport Management: Embracing Esport Education and Research Opportunities. Sport Management Review, 713.

Gençlik ve Spor Bakanlığı E-Spor Raporu (2018). Erişim Adresi https://www.guvenlioyna.org.tr/dosya/7UOTx.pdf Erişim Tarihi 07.07.2021

Gibson, H.J. (1998). Active Sport Tourism: who Participates? Leisure studies, 17 (2), 155- 170.

Gider, T. (2019). E-Spor Ekonomisi. Erişim Adresi https://www.turksporajansi.com/ESpor-ekonomisi-1550207 Erişim Tarihi 08.07.2021.

Güdük, T. (2019). Mersin İlinin Spor Turizmi Potansiyelinin Swot Analizi Yöntemiyle Incelenmesi. Yayımlanmamış Yüksek Lisans Tezi, Mersin Üniversitesi, Sosyal Bilimler Enstitüsü, Turizm İşletmeciliği Anabilim Dalı.

Gül, I., Kızılırmak, I., Güler, E. ve Erhan, Z. Y. (2017). Fuar Turizmi Kapsamında Oyun Fuarları: Gaming İstanbul Örneği. Gazi Üniversitesi Turizm Fakültesi Dergisi 2, 101-120. 
Gündoğdu, N. (2001). Olimpizm ve Olimpiyat Organizasyonları. Ders Notları, İstanbul. Hartmann, T. ve Klimmt, C. (2006). Gender and Computer Games: Exploring Females'

Dislikes. Journal of Computer-Mediated Communication, 910- 931.

İçöz, O. ve Kozak, M. (2002). Turizm Ekonomisi. Ankara: Turhan Kitabevi.

International E-Sports Federation (2021) Erişim Adresi https://ie-sf.org/events/worlds Erişim Tarihi 08.07.2021.

Jenny, S. E., Mannnig, R. D., Keiper, M. C. ve Olrich, T. W. (2017). Virtual(ly) Athletes:

Where eSports Fit Within the Definition of "Sport". Quest, 69(1), 1-18.

Karaman, A. (2016). Otel İşletmeciliği. Konya: Eğitim Yayınevi.

Keçeci, O. ve Çelik, V. O (2021). E-Spor Organizasyonlarında Liderlik: Kuramsal Bir Çerçeve. Spormetre Beden Eğitimi ve Spor Bilimleri Dergisi, 19(2), 1-13.

Kılınç, K. (2019). 2019 Yılının En Çok Gelir Elde Eden Oyunları Açıklandı. Webtekno.

Erişim Adresi https://www.webtekno.com/2019- yilinin-en-cok-kazananoyunlari-h83077.html. Erişim Tarihi 08.07.2021.

Kocadağ, M. (2017). Elektronik Spor Kariyeri ve Eğitim. Doğu Anadolu Sosyal Bilimlerde Eğilimler Dergisi, 1(2), 49-63.

Koç, F. (2021). Dijital Ortamda Sanal Para ile Gerçekleştirilen E-Spor Faaliyetlerinin TMS/TFRS Kapsamında Muhasebeleştirilmesine İlişkin Bir Yaklaşım. Avrupa Bilim ve Teknoloji Dergisi, (25), 34-42.

Lee, S. W., An, J. W. ve Lee, J. Y. (2014). The Relationship Between E-Sports Viewing Motives and Satisfaction: The Case of League of Legends. International Conference on Business, Management \& Corporate Social Responsibility (ICBMCSR'14).

Malin, A. (2018). Esports Tourısm: 5 Events You Need to Attend. Erişim Adresi https://www.abouttimemagazine.co.uk/ london/esports-tourism-5-events-needattend/ Erişim Tarihi: 08.07.2021.

Mustafaoğlu, R. (2018). E-Spor, Spor ve Fiziksel Aktivite. Ulusal Spor Bilimleri Dergisi, 2(2),

Mustafaoğlu, R., Zirek, E., ve Yasacı, Z. (2018). E-Spor Oyuncularının Demografik Özellikleri, Oyun Oynama Süreleri ve Başarılarını Etkileyen Faktörler. Bağımılıı Dergisi, 19(4), 115-122.

Newzoo 2020 Global Esports Market Report, (2020). Erişim Adresi https://newzoo.com/products/reports/global-esports-market-report/ Erişim Tarihi 10.07.2021. 
Bulut Ç, Duman S, Şahin HM, Duman G, Uluç EA. (2021). Spor Turizminde İnovasyonel Yaklaşımlar: E-Spor. Gaziantep Üniversitesi Spor Bilimleri Dergisi, 6(4), 396-412.

Özdemir, B.U. (2020). Fırat Üniversitesi Spor Bilimleri Fakültesinde Eğitim Gören Öğrencilerin Spor Turizmine Yönelik Tutumlarının Incelenmesi. Yayımlanmamış Yüksek Lisans Tezi. Fırat Üniversitesi, Sağlık Bilimleri Enstitüsü, Beden Eğitimi ve Spor Anabilim Dalı. Elâzığ.

Öziş, H. (2017) Sporun Turizme Katkısı. Erişim Adresi http://www.orduolay.com/yazarlar/halil-ozis/sporun-turizme-katkisi/9118 Erişim Tarihi 08.07.2021.

Öztürk, Y. ve Yazıcıoğlu, İ. (2002). Gelişmekte Olan Ülkeler İçin Alternatif Turizm Faaliyetleri Üzerine Teorik Bir Çalışma, Ticaret ve Turizm Eğitim Fakültesi Dergisi, 2, 183-195.

Peichi, C. (2008). New media for social change globalisation and the online gaming industries of South Korea and Singapore. Science Technology and Society, 303-323.

Pişkin, E., Devecioğlu, S. ve Halisdemir, A. (2019). Spor Endüstrisinin Yükselen Alanı E-Sporun Dünya Ekonomisindeki Yeri. İnternational Economic Researches and Financial Markets Congress (IEFRM) Uluslararası Ekonomi Araştırmaları ve Finansal Piyasalar Kongresi.

Ross, S. D. (2001). Developing sports tourism. National Laboratory for Tourism, University of Illinois, Champaign

Seo, Y. (2013). Electronic Sports: A New Marketing Landscape Of The Experience Economy. Journal of Marketing Management, 29(13-14), 1542-1560.

Snavely, T.L. (2014). History and Analysis of Esport System. Doctoral Thesis, The University of Texas at Austin.

Sports Earnings. Top Games Awarding Prize Money Erişim Adresi https://www.esportsearnings.com/games Erişim Tarihi 08.07.2021.

Şakar, S. B. (2021). Dijital Oyunlarda Toplumsal Cinsiyet Kodlarının Yeniden Üretimi: League Of Legends Oyunun Dijital Etnografik Analizi. Yayımlanmamış Yüksek Lisans Tezi, Kocaeli Üniversitesi, Sosyal Bilimler Enstitüsü, Gazetecilik Anabilim Dalı, Gazetecilik Bilim Dalı, Kocaeli.

Şebin, K. (2018). Spor ve Turizm Ilişkisi. Ankara: Nobel Yayıncılık

T.C. Turizm Bakanlığı (1999). Turizm Işsletmeleri Sözlüğü. Ankara: Turizm Bakanlığı Yayınları.

Turgut, F. (2019). Turizm Eğitimi ile Spor Bilimleri Eğitimi Lisans Öğrencilerinin Spor Turizmine Yönelik Tutumlarının Incelenmesi (Düzce Üniversitesi Örneği). 
Yayımlanmamış Yüksek Lisans Tezi, Düzce Üniversitesi, Sosyal Bilimler Enstitüsü, Düzce.

Türkiye Seyahat Acentaları Birliği (2014). Spor Turizmi Raporu. Erişim Adresi www.tursab.org.tr/dosya/12195/tursab-spor-turizmi raporu_12195_5670173.pdf Erişim Tarihi 10.07.2021.

Twentify (2018). Ekrandan Arenaya Espor: Türkiye'deki eGamer ve eSporter Profilini Anlama Araştırması.Twentify Tüketici Araştırması-Lçgörü Temelli Büyüme. Erişim Adresi https://www.twentify.com/tr/raporlar/ ekrandan-arenaya-esporarastirmasi Erişim Tarihi 07.07.2021.

Usta, Ö. (2009). Turizm Genel Yapısı ve Yapısal Yaklaşım. Ankara: Detay Yayıncılık. Üçhisarlı, C. (2017). Türkiye'de E-Spor Pazarı Ne Durumda. Erişim Adresi https://pazarlamasyon.com/turkiyede-e-spor-pazari-ne-durumda/ Erişim Tarihi 10.07.2021.

Üçüncüoğlu, M. ve Çakır, V. O. (2017). Modern Spor Kulüplerinin Espor Faaliyetlerine İlgi Gösterme Nedenleri Üzerine Bir Araştırma. İnönü Üniversitesi, Beden Eğitimi ve Spor Bilimleri Dergisi (IÜBESBD), 4(2), 34- 47.

Wagner, G. M. (2006). On The Scientific Relevance Of E Sports, International Conference on Internet Computing. Amerika: LasVegas.

Yayla, Ö. ve Güven, Y. (2020). Elektronik Sporlar: Rekreasyonel Etkinlik Perspektiften Değerlendirilmesi Dokuz Eylul University Journal of Graduate School of Social Sciences, 22(1).

Yeşil, M. (2015). Antalya'da Spor Turizmi: Mevcut Durumun Tespiti. Yayımlanmamış Yüksek Lisans Tezi, Akdeniz Üniversitesi Sosyal Bilimler Enstitüsü İşletme Anabilim Dalı, Antalya.

Yılmaz, B. (2020). E-Spor Oyuncularının Algıladıkları Sosyal Destek, Aile Iklimi ve Yetişkin Bğlanma Stillerinin Oyun Bağımılı̆̆ı Üzerine Ektisi. Yayımlanmamış Yüksek Lisans Tezi, Hacettepe Üniversitesi, Sosyal Bilimler Enstitüsü, Sosyal Hizmet Anabilim Dalı, Ankara. 